\title{
Implikasi Kepemimpinan Situasional pada Efektivitas Prestasi Kerja TU di Sekolah Menengah Pertama Negeri 23 Semarang
}

\author{
Burhanuddin Chusnul Chuluq, Agus Khunaifi, Fanzal Pamungkas \\ Universitas Islam Negeri Walisongo, Semarang, Indonesia \\ chusnul.burhan@gmail.com
}

\begin{abstract}
This study aims to determine the situational leadership style of the principal at SMP Negeri 23 Semarang City, based on the age factor of the administrative staff at SMP Negeri 23 Semarang, namely the young age of 2 people and the old age of 4 people so that daily tasks in the administrative section are quite hampered. , while in carrying out their duties, the administration must work quickly. This research is a field research with a qualitative approach. The research subjects were the principal and administrative staff. Data obtained by interview, observation and documentation.

The results of this study concluded that there are implications of situational leadership of the principal on the effectiveness of administrative performance seen from the type of situational leadership, namely the first instruction process of the principal to the administrative admin coordinator, the second consultation process between the administration and the principal, resulting in a harmonious relationship and also intertwined two-way communication, the third process of participation when the principal is involved in the work that coincides with the administrative staff and the fourth process of delegation of the principal on administrative performance does not provide training directly to support the performance of the administration.
\end{abstract}

Keywords: Implication, Situational Leadership, Principal, Performance Effectiveness

\begin{abstract}
ABSTRAK
Penelitian ini bertujuan untuk mengetahui gaya kepemimpinan situasional kepala sekolah di SMP Negeri 23 Kota Semarang, berdasarkan faktor usia staf tata usaha di SMP Negeri 23 Semarang, yaitu usia muda sejumlah 2 orang dan usia tua sejumlah 4 orang sehingga tugas harian di bagian tata usaha cukup terhambat, sedangkan dalam menjalankan tugas, tata usaha harus bekerja secara cepat. Penelitian tema kali ini
\end{abstract}

Burhanuddin Chusnul Chuluq, Agus Khunaifi, Fanzal Pamungkas 
merupakan penelitian lapangan yang menggunakan pendekatan kualitatif. Subjek dalam penelitian ini adalah kepala sekolah dan staf tata usaha. Informasi data didapatkan melalui wawancara yang mendalam, pengataman (observasi) dan studi dokumentasi.

Kesimpulan penelitian adalah terdapat implikasi kepemimpinan situasional seorang kepala sekolah pada efektifitas prestasi kerja tata usaha dilihat dari tipe kepemimpinan situasional yaitu pertama proses instruksi kepala sekolah kepada koordinator admin tata usaha, kedua proses konsultasi antara tata usaha dan kepala sekolah, menghasilkan hubungan yang selaras dan juga terjalin komunikasi dua arah, ketiga proses partisipasi ketika kepala sekolah terlibat dalam pekerjaan yang bersamaan dengan staf tata usaha dan keempat proses delegasi kepala sekolah pada prestasi kerja tata usaha tidak memberikan pelatihan secara langsung untuk menunjang prestasi kerja tata usaha.

Kata Kunci: Implikasi, Kepemimpinan Situasional, Kepala Sekolah, Efektivitas Prestasi kerja

\section{LATAR BELAKANG}

Kepemimpinan berasal dari kata "pimpin" artinya diarahkan atau dituntun. Merujuk dari istilah tersebut, maka terbentuk istilah pemimpin, kepemimpinan, dan pimpinan. Pemimpin merupakan seorang dengan jabatan tertinggi dalam sebuah organisasi. Sedangkan istilah kepemimpinan memiliki makna menggunakan sebuah skill yang untuk mengatur sebuah organisasi. Sedangkan istilah terakhir, yaitu Pemimpin yang bermakna sekumpulan orang yang diberikan wewenang lebih atau kehendak guna memimpin aktifitas di sebuah organisasi.

Konsep kepemimpinan merupakan sebuah teori ilmu yang menggabungkan antara teori keilmuan serta skill seseorang dalam sebuah organisasi. Bidang garapan kepemimpinan menuntut adanya kesinambungan antara pemimpin dan anggotanya untuk melakukan sinergitas. Teori kepemimpinan menurut Sumiati, yakni seseorang dengan kekuatannya guna menggerakkan anggotanya dalam sebuah lingkungan kerja. untuk bekerjasama dalam melakukan suatu kegiatan. Sedangkan teori kepemimpinan menurut Karim, merupakan sebuah sinergitas tingkah laku dalam menjernihkan hati, pemikiran, jiwa serta sikap orang lain agar dapat berkontribusi langsung dalam mewujudkan tujuan organisasi. 
Umumnya, perilaku mempengaruhi orang lain akan selalu terkait dengan makna kepemimpinan. Dengan demikian, inti dari aktivitas kepemimpinan adalah menggerakkan daya orang lain untuk mencapai tujuan. Yarim mengutip Gasperz, menyatakan teori kepemimpinan merupakan tahapan proses untuk menggerakkan, memberi inspirasi, memberikan motivasi serta mendorong kegiatan orang lain dalam mencapai target lembaga. Sedangkan menurut Arifin yang mengutip Staqdill menyatakan teori kepemimpinan merupakan sebuah proses mendorong dan memberi semangat dalam beraktivitas terkait dengan tugas anggota kelompok.

Gaya seorang kepala sekolah dalam memimpin sekolah dapat dikombinasikan dengan beberapa gaya lain. Memimpin sebuah sekolah dengan untuk kemajuan lembaga merupakan bahasan yang menarik untuk dibahas, sebab kecocokan antara kepemimpinan satu dengan yang lain selalu disesuaikan dengan kebutuhan yang ada di lapangan. Peneliti berkeyakinan bahwa, teori Hersey dan Blancard mengenai kepemimpinan yang disesuaikan dengan kondisi dan keadaan saat itu juga merupakan gaya memimpin yang paling tepat dan paling pas sebab teori ini dianggap lebih fleksibel dalam mempin rekan atau bawahannya dengan memperhatiakn situasi yang terjadi di lembaga tersebut. Selain itu, gaya situasional ini dapat menciptakan kepemimpinan yang efektif dengan mengintensifkan hubungan atasan dan anggota, dengan demikian anggota dapat menentukan keanggotaan pribadi yang dimiliki pemimpin. ${ }^{1}$

Harsey dan Blanchard mengungkapkan bahwa kepemimpinan situasional berlandaskan pada interaksi sebagai berikut: pertama pemimpin memberikan sejumlah instruksi serta pengarahan, kedua pemimpin memberikan motivasi berupa sosio emosional serta level persiapan ataupun kematangan bawahannya dalam menyelesaikan tanggung jawab demi mencapai sebuah tujuan.

Identifikasi seorang manajer tentang isyarat-isyarat yang terjadi di lingkungannya menjadi hal yang mutlak untuk dikuasai, akan tetapi kemampuannya dianggap belum mumpuni terutama dalam memberikan contoh perilaku yang hasanah. Seorang pemimpin harus mampu mengarahkan seorang manajer dalam melaksanakan adaptasi lingkungan

${ }^{1}$ Asep Dika Hanggara, Kepemimpinan Empati Menurut Al-Qur'an (CV Jejak (Jejak Publisher), 2019). 
tempat kerja untuk mengaplikasikan kebijakannya tersebut. Tingkat fleksibilitas juga harus dimiliki oleh seorang kepala sekolah dalam menangani serta menyelesaikan masalah di lingkungan kerja. Kebutuhan yang berbeda dengan bawahannya membuat kepala sekolah mendapatkan perlakuan khusus dibanding dengan bawahannya, sebab kepala sekolah memiliki wewenang lebih dalam mengatur dan melaksanakan program sekolah hingga mencapai keberhasilan. Adapula sebagian pemimpin yang beranggapan bahwa kepemimpinan tidak akan berjalan efektif jikalau seorang pemimpin terlebih dahulu harus mempertimbangkan setiap variabel situasi dalam setiap pengambilan keputusan. Adapun adopsi model kepemimpinan situasional sebagai berikut:

1. Pemimpin memberikan arahan, bimbingan serta pengarahan tugastugasnya

2. Pemimpin memberikan motivasi sosio emosional perihal interaksi/hubungan

3. Anggota memperlihatkan kesanggupan dalam menyelesaikan tanggungjawabnya serta fungsi mereka dalam mencapai sasaran lembaga.

Teori tentang kepemimpinan ini menunjukkan bahwa pemimpin memiliki hubungan yang erat dengan anggotanya sebab pemimpin dan bawahan sama-sama tahu tentang bagaimana keadaan yang terjadi di lapangan, apa yang harus dikerjakan di lapangan, menurut situasi tertentu. ${ }^{2}$ Kepemimpinan situasional ini dianggap efektif sebab sifatnya yang fleksibel hingga dianggap memanusiakan aset sumber daya manusia yang ada.

Gaya kepemimpinan situasional bisa diterapkan untuk mengelola tenaga administrasi, dalam lembaga sekolahan administrasi adalah memberdayakan sekelompok orang membentuk sebuah kejasama dengan upaya mencapai tujuan secara efektif dan efisien. Efektif merupakan antara tujuan yang dicita-citakan dihadapkan dengan hasil kerja keras tepat sasaran, sedangkan efisien bermakna bagaimana pemanfaatan sumber daya yang ada dapat ditekan seminimal hingga bersifat ekonomis. Bagian lain yang urgen adalah administrasi dengan

2 Halla Halla, "Gaya Kepemimpinan Kepala Sekolah SD Muhammadiyah 8 Banjarmasin (Perspektif Teori Kepemimpinan Situasional)," 2018. 
memperhatikan kondisi sumber baik itu berupa tenaga manusia, material barang, keuangan, ataupun waktu. ${ }^{3}$

Administrasi di lembaga sekolah tidak bisa lepas dari bagian Tata Usaha (TU), yang mana bagian tersebut merupakan salah satu aspek penting yang ada dalam organisasi pendidikan, bagian tata usaha tidak bisa dianggap sebelah mata meskipun tidak terjun langsung ke dalam proses pembelajaran siswa di kelas, tidak merumuskan dan menyusun bahan ajar, akan tetapi dibalik itu semua staf tata usaha berupaya keras dan maksimal dalam mengelola seluruh aspek sesuai dengan ruang lingkup tata usaha diantaranya adalah menyimpan, mengganda, menyalin, mencatat, menghimpun, dan mengirim.

Seiring dengan tugas tata usaha yang kompleks, dalam pelaksanaan tugas harian selalu terselesaikan dengan baik karena ada bantuan pekerjaan dari staf muda, dan tugas yang berhubungan dengan pengoperasian komputer justru keadaan anggota tata usaha di SMP Negeri 23 Semarang sebagai sekolah formal yang berstatus sekolah negeri bisa dibilang kurang prima, hal tersebut dapat dilihat dari beberapa anggota tata usaha yang sudah memasuki usia senja, oleh karena itu pendekatan kepemimpinan situasional kepala sekolah sangat dibutuhkan untuk tetap menjaga kualitas pelayanan tata usaha di sekolahan tersebut.

Pendekatan kepemimpinan situasional bisa menjadi salah satu solusi karena kepala sekolah akan selalu menjaga hubungan baik secara individual dengan staf tata usaha, memastikan staf tetap dalam kematangan (maturity) pribadi sesuai dengan tupoksi yang sudah diberikan, menjalankan tugas sesuai dengan apa yang sudah ditargetkan, sehingga bisa menghasilkan pekerjaan yang efektif.

\section{KAJIAN PUSTAKA}

\section{Sekolah Menengah Pertama}

Jenjang sekolah menengah yang pertama adalah SMP, yaitu sebuah jenjang pendidikan formal yang menyelenggarkan pembelajaran secara umum kepada mayarakat sebagai lanjutan dari sekolah Dasar atau Madrasah Ibtidaiyyah ataupun yang sederajat. Pada jenjang SMP, peserta didik terbagi menjadi tiga level kelas yang berbeda, yaitu kelas tujuh,

\footnotetext{
${ }^{3}$ Daryanto, ADMINISTRASI PENDIDIKAN(Jakarta: PT RINEKA CIPTA, 2008).
} 
delapan, dan sembilan. SMP memiliki beberapa fungsi dalam melaksanakan tugas, yaitu:

1) Implementasi pendidikan

2) Pelaksanaan hubungan kerjasama dengan wali murid, komite sekolah, dan masyarakat

3) Pelaksanaan administrasi ${ }^{4}$

\section{Kepemimpinan Kepala Sekolah}

Bafadal (2003) memaparkan bahwa kepemimpinan merupakan proses untuk mempengaruhi, mengajak, mendorong, memotivasi dan menggerakkan orang lain secara bersama-sama dalam proses kerjasama disesuaikan peraturan yang berlaku guna mencapai cita-cita bersama. Ini artinya kepemimpinan dimaknai sebagai suatu proses yang dilakukan untuk mempengaruhi seseorang atau sekelompok orang untuk bekerja secara bersama-sama tanpa adanya paksaan demi wujudkan cita-cita lembaga. Kepemimpinan dimaknai sebagai mengarahkan dan mempengaruhi penyelesaian tugas-tugasnya yang berhubungan dengan tanggungjawabnya anggota dalam sebuah organisasi.

Kepemimpinan memuat maknsa seluruh komponen lembaga ikut bergerak, baik atasan maupun bawahan dalam rangka memenuhi target lembaga. Tiga implikasi penting yang termuat dalam dalam hal ini, yaitu orang lain selalu dilibatkan dalam sebuah praktik kepemimpinan, kepemimpinan memuat tentang pelimpahan wewenang kepada bawahannya, pemimpin memiliki hak prerogratif untuk mengatur bawahannya dalam sebuah organisasi demi terwujudnya tujuan.

Kepemimpinan memilikihakikat yang melekat seperti memberikan sebuah contoh nyata kepada anggotanya; (2) skill untuk menggerakkan orang lain untuk mencapai tujuan; (3) kemampuan memberi inspirasi, dan mengarahkan tindakan seseorang atau kelompok untuk mencapai tujuan; (4) pimpinan, pengikut, dan kondisi tertentu merupakan unusr-unsur yang terlibat; (5) kemampuan memotivasi sebuah golongan untuk mencapai tujuan. ${ }^{5}$

\footnotetext{
${ }^{4}$ PEDOMAN PENDIRIAN and SATUAN PENDIDIKAN DASAR D A N MENENGAH, "PERATURAN MENTERI PENDIDIKAN DAN KEBUDAYAAN REPUBLIK INDONESIA NOMOR 36 TAHUN 2014" (BSNP, 2019). Media, 2014).

${ }^{5}$ Andang, Manajemen Dan Kepemimpinan Kepala Sekolah (Yogjakarta: Ar-Ruzz
} 
Buku Management karya Koontz, dkk menyatakan bahwa kepemimpinan secara umum adalah seni menggerakkan orang lain, sehingga dengan penuh kerelaan membantu lembaga untuk mencapai tujuan. Adapun fungsi kepala sekolah antara lain:

1) Adanya motivasi dan keinginan yang kuat dari guru, karayawan dan peserta didik dalam menyelesaikan tugas masing-masing.

2) Membimbing serta mengarahkan guru, staf, dan peserta didik serta memberikan dorongan untuk semakin terdepan serta memberikan inspirasi sekolah dalam mencapai tujuan. ${ }^{6}$

Kepribadian seseorang sangat berpengaruh dengan kepemimpinannya atau cara kepala sekolah memimpin yang tercermin dalam sifat-sifat berikut:

1) Bersikap jujur

2) Memiliki kepercayaan diri yang tinggi

3) Bertanggung jawab

4) Berani memutuskan sesuatu serta menghadapi resiko

5) Memiliki jiwa yang tanggung

6) Emosi yang terkendali

7) Teladan $^{7}$

\section{Pendekatan Situasional}

Pendekatan kepemimpinan situasional adalah pemahaman seorang pemimpin mengenai berbagai tingkah laku, perilaku, dan kondisi dalam keadaan tertentu dengan mengaplikasikan beberapa gaya kepemimpinan yang dadopsi menurut keyakinannya dalam sebuah lingkungan tertentu. Pendekatan situasional menitik beratkan seorang pemimpin yang mampu menata tingkah laku anggotanya dengan keahlian yang dimiliki pemimpin tersebut. ${ }^{8}$ Teori situasi (Situational Theory) yaitu teori yang beranggapan bahwa munculnya seorang pemimpin dengan berbagai keahlian dan ketrampilan yang mampu memberikan solusi-solusi atas masalah yang ada pada sebuah kelompok dalam situasi tertentu.

\footnotetext{
${ }^{6}$ Muhammad Ali Hanafiah, "Kepala Sekolah Sebagai Pemimpin Dan Supervisor," Hikmah 15, no. 1 (2018): 86-92.

${ }^{7}$ Hanafiah.

${ }^{8}$ Andang, Manajemen Dan Kepemimpinan Kepala Sekolah.
} 
Lebih jelasnya kepemimpinan merupakan suatu fungsi, dan dalam kontek ini dapat dikatakan bahwa untuk memahami kepemimpinan secara komprehensif hendaknya meliputi unsur-unsur berikut:

a) Perilaku pemimpin

b) Perilaku pengikut

c) Situasi dalam kepemimpinan itu berlangsung

Walaupun demikian, kenyataannya unsur-unsur tersebut sangat sulit untuk dianalisis secara terpisah. Namum pemikiran ini merupakan dasar dari teori kepemimpinan situasional (Situational Theory). Teori ini berasumsi bahwa harus terdapat suatu pertukaran pendapat yang positif diantara pemimpin dan para pengikutnya agar dapat mencapai tujuannya.

Kepemimpinan situasional dapat diartikan sebagai performa yang ditampilkan oleh pemimpin untuk mempengaruhi para pengikutnya untuk melakukan tugas atau pekerjaan spesifik dengan memperhatikan taraf kematangan, sehingga terciptanya kesepakatan, kesesuaian, maksud dan kekompakan dalam lingkungan kerja. ${ }^{9}$

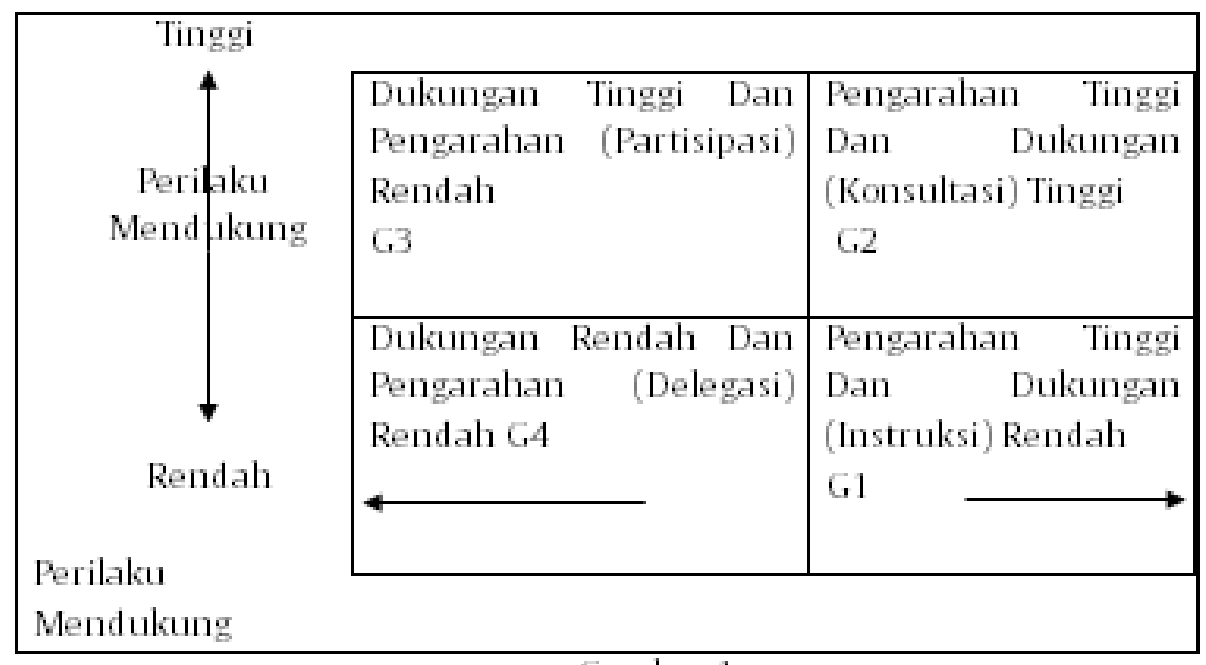

Gambar 1

Model Kepemimpinan Situasional dalam 4 Gaya

Thoha mengutip Hersey dan Blanchard menyatakan bahwa 4 gaya dasar kepemimpinan situasional sebagai berikut:

9 Ejeng Suryana, Administrasi Pendidikan Dalam Pembelajaran (Yogyakarta: DEEPUBLISH, 2015). 
1. Telling, yaitu dalam pelaksanaan yang terjadi ialah pemimpin merealisasikan dan menerjemahkan tujuan organisasi yang kemudian digerakkan melalui anggotanya sehingga anggota dibawahnya memahami ruang lingkup job discriptionnya masingmasing kapan mulai dan berakhirnya tugas tersebut.

2. Selling, yaitu interaksi yang intensif antara pimpinan dan bawahannya berlangsung secara berkesinambungan yang membuahkan konsep kerja keras keduanya yakni atasan mengarahkan dan bawahan melaksanakan instruksi tersebut.

3. Participating yaitu perilaku seorang pemimpin yang memberikan kelonggaran serta peran besar kepada anggotanya untuk berpartisipasi secara aktif, sehingga semua karyawan mampu berperan aktif, organisasi menjadikan dinamis dan semua orang dalam organisasi tersebut bekerja sesuai peran dan tanggung jawabnya masing-masing.

4. Delegating yaitu perilaku pimpinan mampu menjadikan anggotanya untuk menjadi delegasi ketika dibutuhkan serta memberikan kesempatan untuk mengambil keputusan sesuai porsi kewenangannya. ${ }^{10}$

\section{Administrasi Tata Usaha}

Administrasi terdiri dari dua kata, dan masing-masing kata mempunyai makna tersendiri, administrasi terdiri dari kata Ad yang bermakna intensif dan ministrare yang bermakna membantu, melayani, atau mengarahkan. Dengan demikian administrasi secara etimologis adalah memberikan pelayanan, bantuan serta memberikan arahan secara intens. Administrasi dalam arti sempit yaitu pengaturan atau tata kelola berkaitan dengan ketatausahaan secara sistematis. Makna administrasi secara luas menurut Pradjudi Admo-sudirjo adalah menciptakan serta mengembangkan organisasi beserta manajemen di dalamnya. Soepardi juga menyatakan bahwa administrasi adalah sekelompok orang yang melakukan proses kegiatan secara bersamaan dan simultan untuk mewujudkan visi misi dan tujuan organisasi. ${ }^{11}$

${ }^{10}$ Sitti Aisyah and Soltan Takdir, "Implementasi Gaya Kepemimpinan Situasional Kepala Sekolah Di Smp Negeri 1 Wamena Kabupaten Jayawijaya," Jurnal Kepemimpinan Dan Pengurusan Sekolah 2, no. 2 (2017): 119-32.

${ }^{11}$ Nurochim, Administrasi Pendidikan (Bekasi: Gramata Publishing, 2016). 
Engkoswara memaknai administrasi pendidikan sebagai pengelolaan sumber daya yang dimiliki oeleh organisasi berupa manusia, sistem, belajar, sumber belajar dan fasilitas untuk mencapai tujuan pendidikan secara komprehensif serta mencipatakan kondisi organisasi yang kondusif. Definisi ini menjelaskan bahwa administrasi mampu meningkatkan kualitas dan mutu untuk para administrator pendidikan, guru, dan murid sebagai sumber daya manusia apabila dikelola dengan tepat. $^{12}$

Tujuan administrasi menurut Sergiovanni dan Carver yaitu: produk yang efektif dan efisiensi, adaptiveness serta kepuasan kerja. Tujuan administrasi tersebut sebagai kriteria untuk penentuan kesuksesan dalam mewujudkan penyelenggaraan pendidikan di suatu sekolah. Dengan demikian administrasi pendidikan berperan dalam menunjang tercapainya sebuah tujuan institusional pendidikan untuk semua tingkat dan jenis sekolah.

Menurut Pedoman Pelayanan Perguruan Tinggi, tata usaha adalah seluruh kegiatan pengaturan surat-menyurat mulai dari menerima, mencatat, mengolah, mengadakan, mengirim, dan menyimpan seluruh bahan keterangan yang dibutuhkan untuk lembaga. Tata usaha itu sendiri merupakan bagian yang tidak terpisahkan dari administrasi. Secara umum, tata usaha memiliki peran sebagai berikut: memberikan service pelaksanaan pekerjaan-pekerjaan operatif untuk mewujudkan tujuan lembaga, memberikan penjelasan atau keterangan bagi pimpinan organisasi guna mengambil tindakan yang tepat, membantu kelancaran perkembangan organisasi sebagai suatu keseluruhan. Tata usaha bisa diartikan sebagai karyawan yang memberikan pelayanan dan melaksanakan sebuah pekerjaan operatif untuk orang lain dengan penjelasan yang logis dan dapat menggembarkan seluruh kondisi lembaga. Penjelasan yang diberikan oleh karyawan TU tersebut haruslah memuat sesuatu yang memudahkan tercapainya tujuan lembaga.

Litlefield dan Peterson menyatakan peranan pokok dari TU adalah sebuah tanggung jawab dalam ruangan tidak bisa dikategorikan sebagai kegiatan yang mengarah kepada fungsi-fungsi produksi, penjualan, keuangan, teknik, pembelian, kepegawaian atau fungsi lainnya. Ruang lingkup pekerjaan TU dalam sebuh kantor memuat sebagai sebuah proses

${ }^{12}$ Dadi Permadi, "Kepemimpinan Mandiri (Profesional) Kepala Sekolah," PT. Sarana Panca Karya. Bandung, 2001. 
yang dipergunakan guna melaksanakan salah satu dari fungsi-fungsi tersebut.

Dengan kata lain, tata usaha menjadi bagian kantor yang bertanggung jawab menjadi fungsi penyedia keterangan dan menjadi penjelas dalam rangka membantu pimpinan sesuai organisasi dalam membuat keputusan dan melakukan tindakan yang tepat sasaran. Adapun tujuan akhir dari bagian tata usaha adalah mampu berperan aktif kaitannya dengan keberlangsungan hidup organisasi serta pengembangannnya sebab fungsinya sebagai pusat informasi dan sumber dokumen. ${ }^{13}$

\section{Ekeftifitas Prestasi Kerja Tata Usaha}

Kurniawan mengutip James Gibson menyatakan bahwa efektivitas sebagai upaya mencapai sebuah sasaran yang ditargetkan oleh sebuah lembaga dan pada akhirnya efeknya berimbas pada masyarakat. artinya seluruh stakeholder yang bersangkutan mampu menikmat dan merasakan hasil dari sebuah pencapaian tersebut. Efektivitas itu sendiri berhubungan dengan terlaksananya semua tupoksi, tercapainya sebuah tujuan, memiliki efisiensi waktu, adanya peran aktif dari anggota serta kaitannya anatara hasil dan tujuan yang menunjukkan keberhasilan dalam pencapaian hasil yang diinginkan. Sebuah prestasi kerja yang buruk akan memberikan dampak negatif terutama terhambatnya sebuah pencapaian tujuan lembaga dalam mencapai sasaran. ini artinya ada sistem yang tidak bekerja dengan maksimal sehingga kriteria yang igin diwujudkan menjadi terhambat. ${ }^{14}$

Istilah prestasi kerja menhgandung makna Job Performance atau Actual Performance, yang berarti sebuah capaian hasil prestasi oleh seseorang. Davis menyatakan bahwa "performance: the outcomes, or end results, are typically measured in various forms of three criteria: quantity and quality of products and services; level of customer service".

Prestasi kerja merupakan suatu hasil akhir ukurannya didasarkan pada beberapa kriteria yaitu quantity, quality dan service kepada pelanggan. Menurut Wilson prestasi kerja (performance) merupakan

${ }^{13}$ Daryanto, ADMINISTRASI PENDIDIKAN.

14 Jumalia Mannayong dan Raimurti Djafar, "Efektivitas Kinerja Pegawai Pada Dinas Pendidikan Pemuda Dan Olah Raga Kabupaten Takalar," Jurnal Administrasi Negara Volume 24, no. 2 (2018): 81-82. 
adalah buah hasil kerja keras seseorang dengan memenuhi syarat-syarat tertentu. Sedangkan Hamzah dan Nina yang mengutip Simamora menyatakan bahwa prestasi kerja adalah suatu kondisi tingkah laku manusia yang dicapai dengan persyarat yang berlaku. ${ }^{15}$

\section{Efektifitas Implikasi Kepemimpinan Situasional Kepala Sekolah pada Prestasi kerja Tata Usaha}

Efektifitas yang berkaitan dengan terlaksananya seluruh pekerjaan pokok, tercapainya tujuan, ketepatan waktu, dan peran aktif anggota tidak bisa terlepas dari gaya kepemimpinan situasional kepala sekolah, dalam hal ini kepala sekolah dituntut untuk berperan memahami kondisi dan situasi di lingkungan bagian tata usaha. Implikasi atau dampak yang terjadi dalam pelaksanaan kepemimpinan situasional merupakan tolak ukur seberapa jauh efektifitas kepemimpinan situasuional kepala sekolah yang diterapkan atau dilaksanakan dalam sebuah lembaga pendidikan, hal tersebut bisa dilihat dari beberapa indikator efektifitas prestasi kerja tata usaha yang telah tercapai.

Berdasarkan uraian di atas, efektivitas prestasi kerja merupakan usaha pencapaian tujuan yang telah disetujui banyak orang dengan memperhatikan tiga kriteria, yaitu kuantitas dan kualitas produk serta layanan berupa tingkat pelayanan pelanggan.

\section{METODE PENELITIAN}

Jenis penelitian dalam tema kepemimpinan situasional terhadap prestasi kerja TU menggunakan case study. Studi kasus adalah merupakan metode yang hendak mendalami suatu kasus tertentu secara lebih mendalam dengan melibatkan beberapa sumber informasi. ${ }^{16}$

Pendekatan penelitian yang digunakan dalam tema kepemimpinan situasional terhadap prestasi kerja TU adalah pendekatan kualitatif, yakni penelitian yang tidak ada sangkut pautnya dengan angka-angka atau perhitungan, melainkan menggambarkan hasil penelitian yang didapat langsung dari lapangan dengan

${ }^{15}$ AMIRUDIN AMIRUDIN, "KINERJA PEGAWAI TATA USAHA DENGAN MUTU LAYANAN ADMINISTRASI DI MADRASAH," Al-Idarah: Jurnal Kependidikan Islam 7, no. 1 (2017): 126-45.

${ }^{16}$ J R Raco, "Metode Kualitatif (Jenis, Karakteristik, Dan Keunggulannya)," Grasindo. Grasindo, 2010. 
mendeskripsikan, memilih, menyusun dan mengembangkan kata-kata atau kalimat untuk memperoleh sebuah kesimpulan yang tepat. ${ }^{17}$ Penelitian kualitatif juga menekankan kepada realitas sosial sebagai suatu hal yang integral, memiliki kompleksitas, bersifat dinamis interaktif, untuk mengetahui kondisi sesuai alamiahnya, obyektifitasnya dengan kata-kata yang diperoleh berupa kata, kalimat, skema, dan gambar. $^{18}$

\section{HASIL DAN PEMBAHASAN}

\section{Kepemimpinan Situasional Kepala Sekolah}

Gaya kepemimpinan situasional menurut Thoha yaitu gaya instruksi, konsultasi, partisipasi, dan delegasi.

\section{1) Instruksi}

Terkait dengan kondisi yang ada, pada prinsipnya, ada proses instruktif, ada komunikatif, ada partisipatif, ada delegatif, jadi sesuai pekerjaan yang harus dilaksanakan, untuk instruksi yang kepala sekolah berikan biasanya melalui koordinator admin terlebih dahulu karena kormin merupakan orang yang bertanggung jawab terhadap kegiatan tata usaha, terkait adanya pekerjaan yang kurang tepat atau bahkan tidak bisa dilakukan dengan baik, maka kepala sekolah akan memberikan instruksi ke kormin agar bisa disampaikan kepada staf yang lain. ${ }^{19}$ Proses instruksi sudah disampaikan setiap pagi, selebihnya sudah ada di Surat Keterangan Tenaga Kependidikan atau yang biasa disebut SK Tendik.

Kepala sekolah mengarahkan seluruh staf tata usaha dengan pengarahan yang bagus sesuai dengan SOP yang ada. Sudah memberi instruksi ke kormin dengan baik dan juga berjalan dengan baik, sudah ada penerapan disiplin kerja, ${ }^{20}$ untuk instruksi dari kepala sekolah selama ini sudah sesuai SOP, jika ada instruksi mendadak yang harus dikerjakan oleh tata usaha maka akan langsung disampaikan ke staf tata usaha, untuk tugas harian sudah berjalan

\footnotetext{
${ }^{17}$ Nana Syaodih Sukmadinata, Metode Penelitian Pendidikan (Bandung: Remaja Rosdakarya, 2007).

${ }^{18}$ Sugiyono, Metode Penelitian Administrasi (Bandung: Alfabeta, 2005).

${ }^{19}$ Kumpulan Hasil wawancara di SMP Negeri 23 Semarang dengan Anwar Kumaidi, kepala sekolah SMP Negeri 23 Semarang pada 24 November 2020

${ }^{20}$ Kumpulan Hasil wawancara di SMP Negeri 23 Semarang dengan Rina Sinaryu Jatiningsih, koordinator admin SMP Negeri 23 Semarang pada 24 November 2020
} 
dengan baik sesuai instruksi, memang terkadang ada yang yang situasional juga, misalkan perlu sesuatu yang mendadak dan cepat mau tidak mau harus diselesaikan pada hari itu juga. ${ }^{21}$

2) Konsultasi

Konsultasi yang terjadi biasanya kepala sekolah langsung menuju ke koordinator terlebih dahulu, kormin merupakan tujuan utama, ada masalah apapun kepala sekolah langsung menuju ke koordinator terlebih dahulu, setelah dirasa masalah tersebut perlu dikonsultasikan kepada staf tata usaha maka koordinator admin akan menginformasikan ke seluruh staf. Pelaksanaannya sejauh ini tidak ada masalah apapun, jadi proses konsultasi berjalan dengan baik, staf tata usaha juga bekerja dengan baik sesuai deskripsi pekerjaan masing-masing. ${ }^{22}$

Apabila pekerjaan tersebut bisa berjalan secara lancar maka kepala sekolah akan mengikuti apa yang sudah dilakukan staf tata usaha, akan tetapi jika dalam pekerjaan tata usaha kepala sekolah masih merasa keberatan, akan dicari solusi lain, jadi hubungan timbal balik berjalan dengan baik, saling melengkapi dan tetap berkomunikasi dengan baik..$^{23}$

3) Partisipasi

Bentuk partisipasi dari kepala sekolah biasanya ketika memberikan tugas tambahan, kepala sekolah memberikan contoh terlebih dahulu terkait mengerjakan tugas tambahan tersebut, dan apabila masih ada kebingungan maka kepala sekolah akan turun tangan lagi, jadi ada kerjasama antara kedua pihak. ${ }^{24}$

Proses ini lebih terarah kepada kebutuhan kalau ada yang diperlukan apa, ada kekurangan apa, maka koordinator akan menyampaikan ke kepala sekolah, dan kepala sekolah akan berupaya berpartisipasi dalam memenuhi kebutuhan tata usaha, begitupula dengan kendala tugas harian, jika kepala sekolah lebih tau maka staf

${ }^{21}$ Kumpulan Hasil wawancara di SMP Negeri 23 Semarang dengan Umi Rizkiyah, guru BPTIK SMP Negeri 23 Semarang pada 24 November 2020

${ }^{22}$ Kumpulan Hasil wawancara di SMP Negeri 23 Semarang dengan Winda Puspita Sari, staf pengelola peserta didik SMP Negeri 23 Semarang pada 24 November 2020

${ }^{23}$ Kumpulan Hasil wawancara di SMP Negeri 23 Semarang dengan Sriwati, staf pengadministrasi kependidikan SMP Negeri 23 Semarang pada 24 November 2020

${ }^{24}$ Kumpulan Hasil wawancara di SMP Negeri 23 Semarang dengan Winda Puspita Sari, staf pengelola peserta didik SMP Negeri 23 Semarang pada 24 November 2020 
tata usaha akan diarahkan, disupport, dan untuk melakukan pekerjaan tersebut. ${ }^{25}$

4) Delegasi

Selama ini pendelegasian sistemnya ketika ada undangan dari dinas pendidikan, pelatihan-pelatihan itu lebih banyak kita kirimkan ke dinas pendidikan, jadi dari sekolahan sendiri tidak ada pelatihan khusus untuk tata usaha, kalau sekolah mengadakan pelatihan tidak memungkinkan karena pesertanya hanya dua atau tiga orang, sehingga pelatihan itu menunggu dinas pendidikan mengadakan pelatihan, jadi memang kendalanya di situ, tetapi kalau pelatihan yang sederhana, petunjuk dalam pelaksanakan tugas harian ada langsung dari kepala sekolah secara personal, dan ketika mereka sudah mahir dalam tugasnya kepala sekolah hanya mengontrol kinerjanya saja agar tidak menurun. ${ }^{26}$

Proses untuk pengembangan SDM, sampai saat ini tidak ada program pelatihan khusus dari kepala sekolah, akan tetapi biasanya jika aka ada aplikasi baru akan ada bimbingan teknis yang berjalan selama satu hari di dinas, skill dan pengetahuan di refresh lagi, jadi sistem delegasinya setiap ada event dan tidak bisa ditentukan oleh sekolah, contohnya dalam sarana prasarana mengenai aplikasi SIMBADA, tata usaha ditugaskan ke dinas pendidikan untuk belajar mengenai SIMBADA, baru setelah pelatihan dari dinas selesai staf tata usaha bisa mengerjakan tugasnya dengan mandiri, pendelegasian tugas harian juga sudah baik. ${ }^{27}$

\section{Efektifitas Prestasi Kerja Tata Usaha}

Berdasarkan indikatornya, staf tata usaha SMP Negeri 23 Semarang bisa dikatakan bekerja dengan efektif karena:

a. Terhitung dalam satu minggu pekerjaan surat-menyurat, pembukuan surat masuk dan surat keluar, pengelolaan administrasi guru, karyawan dan juga siswa telah berjalan lancar, tepat sasaran dan tepat waktu;

\footnotetext{
${ }^{25}$ Kumpulan Hasil wawancara di SMP Negeri 23 Semarang dengan Sustriasih, staf pengelola peserta didik SMP Negeri 23 Semarang pada 24 November 2020

${ }^{26}$ Kumpulan Hasil wawancara di SMP Negeri 23 Semarang dengan Anwar Kumaidi, kepala sekolah SMP Negeri 23 Semarang pada 24 November 2020

${ }^{27}$ Kumpulan Hasil wawancara di SMP Negeri 23 Semarang dengan Rina Sinaryu Jatiningsih, koordinator admin SMP Negeri 23 Semarang pada 24 November 2020
} 
b. Salah satu bentuk partisipasi staf tata usaha ketika koordinator admin menyampaikan ke kepala sekolah terkait kendala yang dialami staf tata usaha, dan kepala sekolah akan berupaya berpartisipasi dalam memenuhi kebutuhan tata usaha, tentunya juga dengan keikitsertaan kormin dalam mencari solusi karena kormin merupakan penanggungjawab bagian tata usaha;

c. Secara garis besar staf tata usaha telah mencapai tujuan pekrjaan harian mereka sesuai tugas-tugas yang sudah tercantum di SK Tendik, dan pekerjaan berjalan baik, untuk evaluasi tahun kemarin staf tata usaha dapat dikatakan bekerja dengan baik, semua tugas harian dapat terselesaikan dan mencapai target yang telah ditentukan, contohnya dalam satu minggu ada 30 surat masuk, maka yang dibukukan sudah sesuai jumlah tersebut, ya kurang lebih begitu dan itu menyeluruh untuk pekerjaan lainnya. ${ }^{28}$

\section{Implikasi Kepemimpinan Situasional Kepala Sekolah pada Efektifitas} Prestasi Kerja Tata Usaha

Terkait dari hasil uraian pernyataan di atas dapat peneliti simpulkan bahwa terdapat implikasi kepemimpinan situasional kepala sekolah pada efektivitas prestasi kerja tata usaha bagian administrasi dengan catatan sebagai berikut:

a. Proses instruksi terjadi setiap harinya, dimana kepala sekolah memberikan briefing pagi yang dihadiri koordinator admin (kormin) tata usaha, kemudian kormin menyampaikan instruksi ke seluruh staf tata usaha, disamping itu juga terdapat tugas harian yang sudah tertulis di SK Tendik;

b. Proses konsultasi antara tata usaha dengan kepala sekolah juga terjadi, dimana staf tata usaha telah mendapatkan hubungan yang selaras dan juga terjalin komunikasi dua arah, yang artinya ketika staf tata usaha mengalami beberapa kendala, menyampaikan pendapat, dan berbagai macam konsultasi yang lain, kepala sekolah sudah menunjukkan sikap bahwa beliau bersikap egaliter, mendengarkan saran, mensupport dan menjaga relasi dengan baik, sehingga staf tata usaha bisa mengerjakan pekerjaan sesuai target dan tujuan mereka;

\footnotetext{
${ }^{28}$ Kumpulan Hasil wawancara di SMP Negeri 23 Semarang dengan Anwar Kumaidi, kepala sekolah SMP Negeri 23 Semarang pada 24 November 2020
} 
c. Partisipasi kepala sekolah pada efektivitas prestasi kerja tata usaha bisa dilihat ketika kepala sekolah terlibat dalam pekerjaan yang bersamaan dengan staf tata usaha, sebagai contohnya yaitu kepala sekolah berkolaborasi dalam memecahkan masalah yang ada di staf tata usaha, saling bertukar ide, melibatkan staf tata usaha dalam perencanaan kegiatan. Selain itu ada kelemahaan dan kelebihan, dimana kelemahaan staf tata usaha muda menunjukkan sikap kurang sopan dalan proses partisipasi, sedangkan kelebihannya adalah mereka dapat bergerak dengan cepat, mencari ide, solusi yang lebih baik. Disisi lain staf tata usaha yang relatif tua mereka memiliki sopan santun terhadap kepala sekolah, disamping itu kelemahan mereka adalah kurang bisa bekerja dengan baik. Adanya partisipasi tersebut menjadikan staf tata usaha paham akan segala tugas yang harus dilakukan, sehingga mereka sadar dengan tupoksi masingmasing, berkat dukungan dan juga kepercayaan diri yang timbul dari kolaborasi tersebut, prestasi kerja mereka bisa sesuai sasaran.

d. Pelaksanaan proses delegasi kepala sekolah pada prestasi kerja tata usaha tidak memberikan pelatihan secara langsung untuk menunjang prestasi kerja tata usaha, walaupun demikian ada kormin dan salah satu staf yang sering mendapatkan penunjukkan untuk tugas di luar dari dinas pendidikan, hal tersebut terjadi karena staf tersebut masih muda dan juga bisa mengoperasikan komputer, juga keterlibatan kormin dalam pendelegasian sebagai penanggung jawab tata usaha. Sedangkan untuk delegasi tugas harian, contohnya pelayanan masyarakat atau penerimaan tamu, absensi harian guru dan karyawan, pengelolaan administrasi siswa sudah tercapai dengan baik.

\section{KESIMPULAN DAN SARAN}

\section{Kesimpulan}

Setelah menguraikan beberapa data yang peneliti peroleh di SMP Negeri 23 Semarang yang telah terkumpul dan disajikan dalam bentuk deskriptif, maka keterangan dan uraian di atas merupakan suatu bentuk analisa sesuai dengan rumusan masalahnya.

Secara garis besar terdapat implikasi kepemimpinan situasional kepala sekolah pada efektifitas prestasi kerja tata usaha di SMP Negeri 23 
Semarang berdasarkan empat gaya kepemimpinan situasional yang dapat disimpulkan sebagai berikut: Proses instruksi terjadi setiap harinya, dimana kepala sekolah memberikan pengarahan setiap pagi yang dihadiri koordinator admin tata usaha, ada proses konsultasi antara tata usaha dengan kepala sekolah, dimana staf tata usaha telah mendapatkan hubungan yang selaras dan juga terjalin komunikasi dua arah, partisipasi kepala sekolah pada efektifitas prestasi kerja tata usaha bisa dilihat ketika kepala sekolah terlibat dalam pekerjaan yang bersamaan dengan staf tata usaha, pelaksanaan proses delegasi kepala sekolah pada prestasi kerja tata usaha tidak memberikan pelatihan secara langsung untuk menunjang prestasi kerja tata usaha, walaupun demikian ada koordinator admin dan salah satu staf yang sering mendapatkan penunjukkan untuk tugas di luar dari dinas pendidikan.

\section{Saran}

Peneliti memberikan beberapa saran sesuai judul penelitian diantaranya:

1. Bagi Kepala Sekolah SMP N 23 Semarang

a. Sebaiknya perlu melibatkan seluruh staf tata usaha dalam proses briefing harian .

b. Sebaiknya perlu ada pelatihan bagi staf tata usaha walaupun hanya sekali dalam satu semester.

2. Bagi Tata Usaha

a. Sebaiknya lebih meningkatkan pemahaman terhadap prestasi kerja masing-masing;

b. Sebaiknya lebih tepat waktu dalam menyelesaikan tugas yang sudah diberikan.

3. Bagi Peneliti lain yang hendak melakukan penelitian sejenis, diharapkan lebih memahami kepemimpinan kepala sekolah dan juga prestasi kerja tata usaha baik faktor eksternal maupun faktor internal.

\section{DAFTAR PUSTAKA}

Aisyah, Sitti, and Soltan Takdir. "Implementasi Gaya Kepemimpinan Situasional Kepala Sekolah Di Smp Negeri 1 Wamena Kabupaten Jayawijaya." Jurnal Kepemimpinan Dan Pengurusan Sekolah 2, no. 2 (2017): 119-32.

AMIRUDIN, AMIRUDIN. "KINERJA PEGAWAI TATA USAHA DENGAN MUTU LAYANAN ADMINISTRASI DI MADRASAH." Al-Idarah: Jurnal 
Kependidikan Islam 7, no. 1 (2017): 126-45.

Andang. Manajemen Dan Kepemimpinan Kepala Sekolah. Yogjakarta: ArRuzz Media, 2014.

Daryanto. ADMINISTRASI PENDIDIKAN. Jakarta: PT RINEKA CIPTA, 2008. Ejeng Suryana. Administrasi Pendidikan Dalam Pembelajaran.

Yogyakarta: DEEPUBLISH, 2015.

Halla, Halla. "Gaya Kepemimpinan Kepala Sekolah SD Muhammadiyah 8

Banjarmasin (Perspektif Teori Kepemimpinan Situasional)," 2018.

Hanafiah, Muhammad Ali. "Kepala Sekolah Sebagai Pemimpin Dan

Supervisor." Hikmah 15, no. 1 (2018): 86-92.

Hanggara, Asep Dika. Kepemimpinan Empati Menurut Al-Qur'an. CV

Jejak (Jejak Publisher), 2019.

Jumalia Mannayong dan Raimurti Djafar. "Efektivitas Kinerja Pegawai

Pada Dinas Pendidikan Pemuda Dan Olah Raga Kabupaten Takalar."

Jurnal Administrasi Negara Volume 24, no. 2 (2018): 81-82.

Nana Syaodih Sukmadinata. Metode Penelitian Pendidikan. Bandung:

Remaja Rosdakarya, 2007.

Nurochim. Administrasi Pendidikan. Bekasi: Gramata Publishing, 2016.

PENDIRIAN, PEDOMAN, and SATUAN PENDIDIKAN DASAR D A N

MENENGAH. "PERATURAN MENTERI PENDIDIKAN DAN

KEBUDAYAAN REPUBLIK INDONESIA NOMOR 36 TAHUN 2014."

BSNP, 2019.

Permadi, Dadi. "Kepemimpinan Mandiri (Profesional) Kepala Sekolah."

PT. Sarana Panca Karya. Bandung, 2001.

Raco, J R. "Metode Kualitatif (Jenis, Karakteristik, Dan Keunggulannya)."

Grasindo. Grasindo, 2010.

Sugiyono. Metode Penelitian Administrasi. Bandung: Alfabeta, 2005. 